\title{
Divestment and Democracy at a Canadian University ${ }^{1}$
}

\author{
Gregory M. Mikkelson, Cold Hollow to Canada
}

\begin{abstract}
The campaign to divest the endowment of McGill University from fossil fuel has had amazing success in using scientific knowledge to inspire democratic action. Organizations collectively representing all students and academic staff, and most non-academic staff, have voted overwhelmingly in favor of divestment. There is one small problem, however. Unlike Oxford or Cambridge, where a majority vote among all faculty would be the final word about any and all university policy, McGill suffers rule by a plutocratic Board of Governors. This impairment parallels and connects with the stranglehold the fossil fuel industry has on Canadian environmental policy.
\end{abstract}

Keywords: Ecosystem health vs. fossil fuel, democracy vs. plutocracy.

A s of September 2020, more than 1,200 institutions around the world - including 184 institutions of higher education - have rid their investments, worth a total of nearly $\$ 19$ trillion (Canadian), of stock in the fossil fuel industry. ${ }^{3}$ In January 2020, more than 11,000 researchers from 153 countries signed on to an article identifying this global divestment campaign as one of a few "encouraging signs" amid all the "profoundly troubling" statistics in their "World Scientists' Warning of a Climate Emergency." Another prominent scientific article described fossil fuel divestment as a "social tipping intervention" that can "lead to a sufficiently fast reduction in anthropogenic greenhouse gas emissions."

As shown below, the case for divestment from fossil fuel has a strong basis in the natural science, social science, and humanistic scholarship carried out within universities. This has made universities a natural target for local divestment campaigns mounted by the people who work and study there. These efforts have had most success in the UK, where more than half of all universities have committed to purge their endowments of all stock in fossil fuel - or, in a minority of cases, all stock in a sub-category of fossil fuel, such as coal, and/or oil mined from tar sands. ${ }^{6}$ However, in most countries, most universities have not yet made this commitment. Colleagues and I are exploring the characteristics that make some universities more vs. less likely to divest. ${ }^{7}$ In this paper I zero in on the divestment campaign I know best, that of my former place of employment, McGill University.

\footnotetext{
1. Paper presented at the colloquium "Religion and Climate Change," September 20, 2019, at McGill University's School of Religious Studies. Organized by Professor Gerben S. Oegema and Professor David K. Goodin.

2. Based in Montgomery, Vermont, Cold Hollow to Canada is a conservation organization whose vision "is a healthy and intact forested landscape that supports a strong and sustainable local economy through stewardship, with protection of core wildlife habitat and connectivity across the entire Northern Forest." See https://www.coldhollowtocanada.org/who/mission for more information.

3. See https://gofossilfree.org/divestment/commitments.

4. William J. Ripple et al., "World Scientists' Warning of a Climate Emergency,” BioScience 70, no. 1 (January 2020): 812, https://academic.oup.com/bioscience/article/70/1/8/5610806.

5. Ilona M. Otto, et al., Social Tipping Dynamics for Stabilizing the Earth's Climate By 2050," PNAS 117, no. 5 (2020): 2354, https://www.pnas.org/content/117/5/2354.

6. Matthew Taylor, "Half of UK Universities Have Committed to Divest from Fossil Fuel," The Guardian, January 13, 2020, https://www.theguardian.com/environment/2020/jan/13/half-of-uk-universities-have-committed-to-divest-from-fossil-fuel.

7. Greg Mikkelson et al., "University Rank Predicts Divestment from Fossil Fuel.” (In preparation).
} 


\section{The Case for Divestment}

Natural scientists reported more than a decade ago that for global warming to stay below $2.0^{\circ} \mathrm{C}$, fossil fuel corporations must abandon most of the underground reserves they have already discovered. ${ }^{8}$ If global warming exceeds $2.0^{\circ} \mathrm{C}$, projections of future harm run to the millions in premature species extinctions, and to the billions in lost human lives. ${ }^{9}$ Global warming has already depopulated thousands of species, and already kills hundreds of thousands of people each year. ${ }^{10}$ However, all of the mayhem global warming has already visited upon humanity - by exacerbating fires, storms, floods, droughts, heat waves, diarrhea, malnutrition, dengue fever, malaria, etc. - does not yet rank as the worst damage done to our species by fossil fuel. To this point, the respiratory disease and other dysfunctions caused by particulate matter (PM) in fossil fuel exhaust have taken an even greater toll. PM from fossil fuel causes millions of premature human deaths every year - an annual rate similar to that caused by smoking. ${ }^{11}$

Scholars in the humanities and social sciences have further bolstered the moral, political, and even financial case for divestment. For example, historians showed that fossil fuel companies have used the same techniques as tobacco companies - and even employed some of the same people - to mislead citizens about the harms they cause, and thwart government action in the public interest. ${ }^{12}$ A research group at Oxford reviewed previous divestment campaigns, such as from South Africa and tobacco, and concluded that nearly all of them "were successful in lobbying for restrictive legislation affecting stigmatised firms." 13 Economists have demonstrated the need to directly limit production - not just consumption - of fossil fuel. ${ }^{14}$ One reason that should be obvious is that while fossil fuel consumers number in the billions, fossil fuel producers are orders of magnitude fewer. This makes the latter a more efficient target for government control. Studies have found divestment to have either positive or negligible effects on investment returns. ${ }^{15}$

\section{The Campaign for Divestment at McGill}

Before telling a story about McGill (non-)divestment, let me first issue a couple of caveats, introduce two campus organizations implicated in it, and relate a bit of its pre-history. The first caveat is that because I draw upon my own personal experience with the McGill divestment campaign, the story diff-

8. Malte Meinshausen, et al., "Greenhouse-Gas Emissions Targets for Limiting Global Warming to $2.0^{\circ} \mathrm{C}$," Nature 458 (2009), https://doi.org/10.1038/nature08017.

9. See Chris D. Thomas et al., "Extinction Risk from Climate Change," Nature 427 (2004): 145-148, https:// www.nature.com/articles/nature02121, and John Broome, Climate Matters: Ethics in a Warming World (New York: W.W. Norton, 2012).

10. M. Grooten and R. E. A. Almond, eds., Living Planet Report - 2018: Aiming Higher (Gland, CH: WWF). See also: https://www.who.int/heli/risks/climate/climatechange/en.

11. Philip J. Landrigan, et al., "The Lancet Commission on Pollution and Health," Lancet 391, no. 10119 (2018):462-512, https://doi.org/10.1016/S0140-6736(17)32345-0.

12. Naomi Oreskes and Erik M. Conway, Merchants of Doubt: How a Handful of Scientists Obscured the Truth on Issues from Tobacco Smoke to Climate Change (New York: Bloomsbury, 2011).

13. Atif Ansar, Ben Caldecott, and James Tillbury, Stranded Assets and the Fossil Fuel Divestment Campaign: What does Divestment Mean for the Valuation of Fossil Fuel Assets? (Oxford, UK: Smith School of Enterprise and the Environment, 2013), 14, http://www.smithschool.ox.ac.uk/publications/reports/SAP-divestment-report-final.pdf.

14. G. B. Asheim, et al., "The Case For a Supply-Side Climate Treaty," Science 365, no. 6451 (2019): 325-327, 10.1126/science.aax5011.

15. See Toby A. A. Heaps, "What Kind of World Do You Want to Invest In? Corporate Knights, November 16, 2015, https://www.corporateknights.com/channels/responsible-investing/fossil-fuel-investments-cost-major-funds-billions-

14476536, and Arjan Trinks et al., "Fossil Fuel Divestment and Portfolio Performance," Ecological Economics 146 (2018):

740-748, DOI: 10.1016/j.ecolecon.2017.11.036. 
ers from what others would tell. For example, the history below emphasizes action by fellow professors and me within three organizations: the McGill Association of University Teachers (MAUT), Senate, and Board of Governors. But, of course, the whole campaign started with students who have continued to provide its main driving force and organizing genius. While I mention some particular students below, let me here thank a few others with whom I worked closely and/or from whom I learned much about this issue: Kristen Perry, Andrew Stein, Nina Scheer, Aleksandra Conevska, Jacqueline Tam, Annabelle CoutureGuillet, and Guido Powell. Also, much of the account below concerns my own involvement in the divestment campaign, simply because I know that part of the history best - not to create the false impression that my actions were more important than those of my fantastic colleagues. The second caveat is that, for reasons of space and narrative flow, I describe some events in detail while compressing or even failing to mention at all many other important events over the nearly-eight-year course of the campaign. Remarkable to me is how this campaign has built relentlessly from one small victory to another. Given more space and readers' patience, I - not to mention the others involved - could detail many other such successes (and of course some additional failures as well).

I now introduce the two main governing bodies of the university, both of whom have played important roles in the McGill divestment campaign. The first is the Board of Governors, who have the final say about all university policy. The Board has twenty-five members, most of whom do not represent students, faculty, staff, alumnae, or even Québec or Canadian society as a whole. Instead, they represent a corporate elite. ${ }^{16}$ Moreover, the Board appoints most of its own members, with only eight elected by constituencies within the university (two each by students, academic staff, non-academic staff, and the Senate). This contrasts with the University of British Columbia's board, for example, which has a minority elected by constituencies within the university, but a majority appointed by the provincial government rather than appointed by the board itself. ${ }^{17}$ The second group is the McGill Senate. Just over half of Senate's 111 members are academic staff elected by their peers, with a smaller but substantial number of elected students, a still-smaller set of elected non-academic staff, and finally a cadre of Board-appointed administrators from the "top" level (the principal) down to the deans. While Senate is to "exercise general control and supervision over the academic activities of the University," 18 their power is "[s]ubject to the authority and powers of the Board." 19 Nevertheless, they may advise the Board on "any claims and needs of the University or any part thereof." 20

In 1981, Senate passed a resolution advising the Board to "immediately divest McGill University of all financial holdings in corporations, including financial institutions, having investments in the Republic of South Africa." ${ }^{21}$ In response, the Board referred the matter to their own committee, created just a few years before: the Committee to Advise on Matters of Social Responsibility (CAMSR). CAMSR met many times over the following years, and produced many reports, yet by the end of 1985 had still not come around to agreeing with divestment from South Africa. Senate therefore passed another resolution reaffirming their recommendation to divest in November, by a vote of forty-seven to one. ${ }^{22}$ Five days later - with added pre-

16. CAUT, "Do You Know Who Sits On Your Board?" CAUT Bulletin 63, no. 7 (2016): 14-19, https://www.caut.ca/ bulletin/2016/09/do-you-know-who-sits-your-board.

17. "Board of Governors," The University of British Columbia, https://bog.ubc.ca/board-members.

18. Secretariat, "Statutes of McGill University," McGill University, 2017, 6.3.2, https://www.mcgill.ca/secretariat/

files/secretariat/statues_of mcgill_university.pdf.

19. Secretariat, "Statues of McGill," 6.3.

20. Secretariat, "Statues of McGill," 6.3.8.

21. McGill University Senate, "Minutes," March 11th, 1981, McGill University, Montreal, QC.

22. McGill University Senate, "Minutes," November 13th, 1985, McGill University, Montreal, QC. 
ssure from disruptive student protests - the Board finally assented. ${ }^{23}$ Thus, seven years after the first universities divested from South Africa, McGill finally joined the historic campaign that helped eradicate apartheid.

In 2001 I took a job at the McGill School of Environment (MSE) and Department of Philosophy. Shortly thereafter, I began working with colleagues to get a socially responsible pension option for McGill employees. As a result, our pension officers created a supposedly responsible option in 2007 - one invested in some of Canada's most notorious fossil fuel and mining companies. This was my first exposure to McGill "greenwashing": the inclination of the university's central administrators toward false impressions of environmental responsibility. To be fair, these administrators have taken some real steps toward reducing the university's environmental impacts - for example, they authorized the closure of some campus sectors to car traffic, and also the reduction of fossil fuel consumption by university buildings. However, the campaign for divestment from fossil fuel has unmasked a deep complicity between the people who control the institution and vested anti-environmental interests.

\section{The First Five Years of the Campaign}

Because of my role in pushing for a socially responsible pension option, in late 2012 McGill alumnus David Summerhays contacted me on behalf of then-new student group DM. They sought advice on rooting out fossil fuel investments from the university's endowment fund, and wondered if our faculty association might endorse the effort. I submitted a motion along those lines, to the MAUT Council on which I served. Unfortunately, by the time it came up for a vote in early 2013, its seconder Peter Caines had left to teach a class.

After a presentation by alumnus Summerhays, MAUT vice-president (internal) David Harpp asked whether there was any good evidence that fossil fuel companies had spread misinformation about global warming. As noted above, historians had already devoted a well-known book to the subject by that time. ${ }^{24}$ I responded to Harpp by citing the Royal Society of London's (RSL's) condemnation of Exxon for the company's doubt-mongering about anthropogenic global warming. ${ }^{25}$ The RSL is the world's oldest and most prestigious scientific society. I did not know at the time that Harpp had received grant money from, and given presentations to, Exxon's Canadian subsidiary Imperial Oil. ${ }^{26}$

Vice-president (finance) Chris Ragan made several other arguments against the motion (MAUT Council 2013). Ragan now heads the "Ecofiscal Commission," which receives funding from Suncor. ${ }^{27}$ Suncor is McGill's second-largest direct fossil fuel investment (\$3.4 million as of June 30th, 2020), and thirteenth-largest direct investment out of 431 overall. ${ }^{28}$ Suncor owns more oil reserves in the Canadian tar sands than any other corporation in the world, except for McGill's fourth largest fossil fuel investment, Canadian Natural Resources. ${ }^{29}$ The influential Ecofiscal Commission has advocated caps and taxes to limit

23. M. Gordon, "McGill Recognizes Total Divestment," McGill Daily, November 20, 1985.

24. Oreskes and Conway, Merchants of Doubt.

25. Bob Ward, "Letter to Nick Thomas of Exxon," Royal Society of London, September 4, 2006, https://royalsociety. org/ /media/Royal_Society_Content/policy/publications/2006/8257.pdf.

26. See https://www.mcgill.ca/oss/files/oss/harpp_resume.pdf.

27. See https://ecofiscal.ca/the-commission/the-people-behind-the-commission/\#Funders.

28. "Direct" investment as opposed to investment in a pooled fund that includes fossil fuel; McGill's top direct investment in fossil fuel being TC Energy, maker of pipelines for tar sands oil and fracked natural gas. See https://www.mcgill.ca/investments/holdings.

29. A. J. Kirsch, et al., Banking on Climate Change: Fossil Fuel Finance Report Card 2020 (San Francisco, CA: Rainforest Action Network, 2020), https://www.ran.org/publications/banking-on-climate-change-fossil-fuel-finance-report-2020. 
Canadian fossil fuel consumption, but not any direct limits on Canadian fossil fuel production, which makes a far greater contribution to global warming. ${ }^{30}$ Given the composition of MAUT Council in early 2013, my divestment motion went down in flames.

DM therefore submitted their first "expression of concern" (EoC) - a mechanism spelled out in CAMSR's terms of reference - without MAUT support. Later in 2013, the committee and Board dismissed DM's argument for the first time. Far from giving up however, DM then kicked into high gear. Their prodigious level of activity included bountiful public input on revisions to CAMSR's terms of reference, resulting in the phrase "or on the natural environment" being added to their definition of "social injury" as "the grave injurious impact which the activities of a legal person is found to have on consumers, employees, or other persons." 31 DM also began a hugely successful outreach effort that would eventuate in organizations collectively representing not only all students and most non-academic staff on campus endorsing divestment, but also all academics through MAUT. ${ }^{32}$ Their strategy included recruiting a large number of faculty members, whom Professor Darin Barney then coordinated into a named organization McGill Faculty and Librarians for Divestment, or MFL4D - with regular meetings, an e-mail list-serve, etc. Finally, DM submitted a much-expanded (149-page) second EoC to the Board in early 2015.

Once again the Board referred the matter to CAMSR. This time, CAMSR took longer - 13 months - to respond with a recommendation to the Board. During this period, they officially consulted six McGill faculty members. Only five were later identified, none of whom have any academic expertise in socially responsible investment, and at least three of whom, including Ragan, have opposed the divestment campaign. ${ }^{33}$ However, all faculty bodies considering the matter during this time strongly endorsed divestment. For example, Ragan's own Faculty of Arts voted $85 \%$ in favor of divestment, ${ }^{34}$ the Faculty of Law 76\% in favor, and the MSE 91\% in favor. ${ }^{35}$ CAMSR's choice of professors to consult thus seems a classic case of cherry-picking. Moreover, the "report" they finally submitted would have failed as an undergraduate paper at McGill. In stark contrast to DM's exhaustively documented and well-reasoned EoC, the 15-page CAMSR piece offered a shocking dearth of evidence, and laughably fallacious arguments for its claims. ${ }^{36}$

Nonetheless, the Board accepted the CAMSR document a mere 24 hours after receiving it, along with its main recommendation: keep investing in fossil fuel. A number of prominent alumni, including award-winning McGill climate physicist Shaun Lovejoy, responded to this offense against intellectual and

30. See Barry Saxifrage, "Canadians Are Making A Supersized Gamble on Climate and The Economy," National Observer, February 21, 2017, https://www.nationalobserver.com/2017/02/21/opinion/canadians-are-making-super sized-gambleclimate-and-economy; Asheim, et al., "The Case For"; https://ecofiscal.ca/carbon-pricing/fast-facts.

31. CAMSR, "Terms of Reference of the Committee to Advise on Matters of Social Responsibility," McGill University, last modified April 26, 2018, https://www.mcgill.ca/boardofgovernors/committees-0/social\#Terms \%20of\%20Reference. 32. Darin Barney and Derek Nystrom, "McGill Is Still Investing in Fossil Fuels And Has No Plans to Stop," National Observer, December 9, 2019, https://www.nationalobserver.com/2019/12/09/opinion/ mcgill-still-investing-fossil-fuelsand-has-no-plans-stop.

33. McGill Reporter Staff, "Experts Weigh In On Climate Change, Divestment," McGill Reporter, April 7, 2016, https://reporter.mcgill.ca/experts-weigh-in-on-climate-change-divestment/.

34. Gabrielle Fahmy, "Divest McGill Movement Gets Backing From Arts Faculty," CBC News, December 3, 2015, https://www.cbc.ca/news/canada/montreal/divest-mcgill-faculty-arts-vote-1.3348997.

35. McGill School of Environment, "Council Minutes,” January 15th, 2016, McGill University, Montreal, QC.

36. See Peter G. Brown et al., "Letter To The McGill Board of Governors From 12 Angry Professors," May 19, 2016, https://d770c282-fece-4493-9934-28fdee2db642.filesusr.com/ugd/bb851e ad664684cb2a45ec86f25d1d48f218e6.pdf, and CAMSR "Report To The Board On Divest McGill Submission of February 2015," (Annotated by MFLAD), March 17, 2016, https://d770c282-fece-4493-9934-28fdee2db642.filesusr.com/ugd/bb851e d972486e9a194c15aaee5d74c0dc540a. pdf. 
moral integrity by handing back their McGill diplomas, in a kind of reverse graduation ceremony. ${ }^{37}$ Meanwhile, DM occupied the administration building for several days. They left only after Principal Suzanne Fortier agreed to a series of official campus fora on divestment. ${ }^{38}$

After this second refusal to divest from fossil fuel, DM understandably wrote off the official channel of submitting a third EoC to CAMSR. They nevertheless continued to educate, recruit, and organize new students. Meanwhile, MFL4D undertook a strategy of winning elections for various offices. Six of these bids succeeded: Katherine Zien and Dror Etzion won seats on MAUT Council, Eran Shor and I on Senate, and Derek Nystrom and Darin Barney on the Board.

In fall 2017 Zien told her fellow members of MAUT Council about MFL4D's intention to make a divestment motion at the fall general meeting (FGM) of all MAUT members. Then-president Terry Hebert decided to bring it first to MAUT Council. He had confidence it would pass, despite the ill fate of my similar motion there four years before. Council had indeed undergone somewhat of a transformation, withmore people fighting for labor and environmental protection - notably Renee Sieber, who had also playeda crucial role in the MSE divestment motion, and Shor, who also served on Senate as noted above. The motion did pass at Council this time, by a strong majority, and with a call to divest not only the endowment but the pension to boot. A second motion also passed, to divest MAUT's own funds. ${ }^{39}$ The two motions came up at the FGM, but only for discussion since they had already passed at Council. Several people spokein favor of divestment, and none against. ${ }^{40}$ By the end of 2018, then-MAUT-vice-president (finance) Etzion and the rest of the association's finance committee had made MAUT's investments fossil-free.

\section{The McGill Senate Takes a Stand}

Meanwhile, graduate student and fellow senator Nick Dunn nudged me several times about whetherI planned to make a divestment motion at Senate. By April 2018, I mustered the courage to change my answer from "maybe" to "yes." I had balked up to that point, because the central administration dominates the Senate, and they were (and are) bitterly opposed to divestment. Perhaps most crucially, Principal Fortier acts as ex officio chair of both Senate as a whole and its steering committee - the group who censors whatSenate is allowed to discuss. Despite this - thanks to other members of the committee, including Dunn andthenpast-MAUT-president Hebert - Steering did not completely reject my motion.

Instead, they invited me to re-submit in May, with the motion "revised to outline, more clearly, the academic significance of the matter." 41 This is a standard administrators' ploy: trying to boost their own power by limiting senate discussion to "academic" matters. A classic study of university governance in Canada debunked this cant more than half a century ago: ${ }^{42}$

37. Martin Lukacs, "Why Graduates Of A Top Canadian University Are Returning Their Diplomas," The Guardian, March 15, 2016, https://www.theguardian.com/environment/true-north/2016/mar/15/why-graduates-of-a-top-cana dian-universityare-returning-our-diplomas.

38. David Gray-Donald, "McGill Budges Slightly Under Pressure From Fossil Divestment Campaign," Rabble, April 4, 2016, https://rabble.ca/news/2016/04/mcgill-budges-slightly-under-pressure-fossil-fuel-divestment-campaign.

39. McGill Association of University Teachers, "Council Minutes," November 8, 2017, https://mcgill.ca/maut /files/maut/approved_minutes_for_council_meeting_on_november_8_2017.pdf.

40. McGill Association of University Teachers, "Council Minutes," November 17, 2017, https://mcgill.ca/maut/files /maut/maut_fgm_minutes_nov_17_2017 th_as_avdb_pr.pdf.

41. Georgia Ntentis, Email to Gregory Mikkelson on behalf of the McGill Senate Steering Committee, April 11, 2018.

42. Thanks to Professor Bruce Reed for bringing this material to my attention, as he prepared arguments for his lawsuit charging that the university deprived him (and all faculty) of his contractual right to collegial governance vis-à-vis divestment. 
The two-tiered system [involving both a senate and a board] can work well only if the Senate is both able and willing to play its full part. It should be the responsible, representative voice of the whole academic community on all, literally all, questions of University policy [...] not excluding matters relating to finance. ${ }^{43}$

McGill's own Joint Governors-Senate Committee on University Governance took its cues from the DuffBerdahl report, and agreed that

Senate's powers, though classically 'academic' are in fact powers which are inevitably intermixing with and parallel to the interests and authority of the Board of Governors, or similar bodies, over basic financial and university-wide administrative questions. Experience leaves no doubt that it is no longer possible, in a well-managed university, where the academic community takes part in broad decision making, to draw sharp lines between academic and financial questions. ${ }^{44}$

Before re-submitting my motion in May 2018, I simply added a reference to the McGill statute adopted in the early 1970's to head off precisely the kind of ploy the Steering Committee was making:

It [Senate] may make such representations, through the Principal, to the Board of Governors as may from time to time become necessary or desirable, touching any claims and needs of the University or any part thereof. ${ }^{45}$

Having put the ball into the other court, I then started contemplating how to actually win the vote at Senate should the motion get through this time. Less than a week before the May Senate meeting, I got word it was on the agenda. Contemplation then morphed into high stress. Looking over the list of senators, I realized I knew only a tiny fraction of them personally. Should the motion fail, I would be responsible for setting the divestment campaign back by years. I opened up about these worries to my father, a retired professor and veteran of many battles within his own University of Kansas. He suggested a second motion at the meeting, to allow discussion but postpone the vote on divestment until the following meeting. When DM member and senator Jed Lenetsky so moved, it seemed to come as a relief to nearly everyone on Senate. It also proved crucial for those of us supporting divestment, since the following meeting was not until September. That gave us the whole summer to organize.

Those who would come through during this period included many who had previously agitated for divestment at McGill, but also several new to the effort. One newcomer was Students' Society of McGill University (SSMU) officer Jacob Shapiro, who organized meetings between students and individual faculty representatives on Senate over the summer. Zien assembled MFL4D and friends toward the end of the summer, for a vital first meeting in quite a while since tapering off in the two and a half years following the Board's second refusal to divest. Nystrom and Barney, in their capacities as the only two Academic Staff Representatives on the Board, sent all elected senators a letter welcoming Senate's input on divestment. This countered Principal Fortier's frequent refrain against re-considering a matter the Board had tried to settle for good in 2016. Professor Caines took time out from his always-very-busy schedule to individually

43. Sir James Duff and Robert O. Berdhal, University Government in Canada: Report of a Commission Sponsored by The Canadian Association of University Teachers and the Association of Universities and Colleges in Canada (Toronto, ON: University of Toronto Press, 1966), 8, 27.

44. Joint Governors Senate Committee, "Report,” 1967, McGill University, 14-15.

45. Secretariat, "Statues of McGill," 6.3.8. 
lobby a good number of senators. And long-time MFL4D activist Gabriella Coleman convinced a reporter to publish a pro-divestment editorial the week before the Senate meeting. ${ }^{46}$

Then, shortly after a demoralizing setback, efforts by Professor Etzion to engage the Canada Research Chair in Climate Change Mitigation and Tropical Forests, Catherine Potvin, bore fruit. Two days before the Senate meeting, I got word that Steering was refusing to let me show the three slides I had sent them 10 days before. ${ }^{47}$ This, despite the norm of various administrators showing long slide shows at Senate, at times with questionable value. A few hours later, however, I got the e-mail to all senators from Potvin. She made a compelling case "to give us hope" by voting for divestment. Her intervention renewed my confidence that we had a fighting chance.

First however, we had to surmount yet another obstacle erected by Principal Fortier, and Provost Chris Manfredi, through their dominion over the steering committee. Steering placed their own bizarre motion before mine on the agenda:

Be it resolved that Senate, on the recommendation of the Steering Committee, state its position on the following question: Given the division of responsibility set for the Board of Governors and the Senate by the Statutes, does Senate, in the context of its academic mandate, think it necessary or desirable to express an opinion on a matter that has been considered by the Board in line with its authority and based on processes and mechanisms that it has established? ${ }^{48}$

Depending on how the vote went on this "pre-motion," it could have prevented the divestment motion from being discussed after all. Manfredi argued that if Senate dared to weigh in on this "non-academic" matter, the Board might retaliate by vetoing "academic" resolutions passed by Senate in the future.

Fortunately, Bryan Buraga - a student at his very first Senate meeting - brilliantly took down Manfredi's arguments. Buraga reminded fellow senators that universities should be all about open debate and deliberation on issues of public importance. At that very point the tide turned toward victory. Senate voted "yes" we do think it necessary or desirable, and so we moved on to the real motion. After my speech, Provost Manfredi rose again to quibble about whether a few of the many other universities cited as divesting really deserved that credit. This time another student at her first senate meeting, Madeline Wilson, followed with well-prepared points. In the end, the divestment motion passed by a crushing majority. ${ }^{49}$

\section{The McGill Central Administration and Board of Governors: From Anti-Ecological, to Anti-Democratic, to Illegal}

Another McGill statute (6.3.9) requires that in such cases of disagreement between the Senate and Board, a joint committee convene to resolve it. ${ }^{50}$ Instead, the Board referred the matter back to CAMSR for a third time, chaired now by former Petro-Canada executive Cynthia Price-Verrault, with Imperial Oil grant recipient Professor Harpp as another member. Moreover, Nystrom and Barney found their attempts to participate in the process as elected Academic Staff Representatives so stymied that the two resigned from

46. Martin Patriquin, "McGill Should Stop Investing in Fossil Fuels," Montreal Gazette, September 5, 2018, https://montrealgazette.com/opinion/columnists/martin-patriquin-mcgill-should-stop-investing-in-fossil-fuels.

47. Georgia Ntentis, Email to Gregory Mikkelson on behalf of the McGill Senate Steering Committee, September 10, 2018. 48. McGill University Senate, "Report of the Steering Committee," September 12, 2018, McGill University, Montreal, QC. Italics and underlining in original.

49. McGill University Senate, "Report of the Steering Committee."

50. Secretariat, "Statues of McGill University." 
the Board on Earth Day 2019. ${ }^{51}$ Sure enough, after stalling again for more than a year, CAMSR advised against divestment yet again. On December 5th, 2019, despite heroic efforts by two other elected Board members - Non-Academic Staff Representative Ehab Lotayef and then-SSMU-president Buraga - the Board accepted CAMSR's recommendation to partly "de-carbonize" McGill's investments instead. We can contrast this insultingly late and weak response with the University of California Board's turnaround to full divestment just two months after their own Senate resolution in $2019 .{ }^{52}$ The University of British Columbia (UBC) offers a contrasting case within Canada. Unlike McGill, the UBC board does not have any members with direct financial ties to the fossil fuel industry. And unlike McGill, UBC is now fully divesting from fossil fuel. ${ }^{53}$

DM loudly denounced the Board for greenwashing. Indeed, minutes after the meeting ended, Principal Fortier misled thousands of people by using the word "divesting" in her e-mail announcement to the McGill community. ${ }^{54}$ In fact, the CAMSR report approved by the Board explicitly disavows divestment from fossil fuel. ${ }^{55}$ Whereas divestment aims to keep most fossil fuel in the ground, so-called "decarbonization" only holds fossil fuel companies responsible for how efficiently they extract their product from the ground. ${ }^{56}$ When the Board defied not only the scientific case for divestment, but also the overwhelming democratic mandate for it from the campus community, and even the university's own ground rules, I could no longer continue working there in good conscience. ${ }^{57}$

\section{Conclusion: McGill as Microcosm of Canada}

The McGill travesty is a synecdoche of an ecocidal contradiction at the heart of Canadian federal policy: claiming to cut fossil fuel consumption, while recklessly expanding fossil fuel production. Both McGill and Canada have committed to ambitious reductions in greenhouse gas emissions over the next few decades. ${ }^{58}$ Meanwhile however, the people who run McGill are directly investing the university's money

51. Darin Barney and Derek Nystrom, "McGill Profs Resign From Board of Governors Over Investment in Fossil Fuels," National Observer, April 22, 2019, https://www.nationalobserver.com/2019/04/22/opinion/mcgill-profs-resign-boardgovernors-over-investment-fossil-fuels.

52. See Jagdeep Singh Bachher and Richard Sherman, "UC Investments Are Going Fossil Free. But Not Exactly For The Reasons You Think," LA Times, September 17, 2019, https://www.latimes.com/opinion/story/2019-09-16/divestmentfossil-fuel-university-of-california-climate-change, and Joshua Emerson Smith, "UC Academic Senate Calls On Regents To Divest From Fossil Fuels," The San Diego Union-Tribune, July 17, 2019, https://www.sandiegouniontribune.com /news/environment/story/2019-07-17/uc-professors-call-on-regents-to-divest-from-fossil-fuels.

53. James Rowe et al., "Why Has UBC Divested From Fossil Fuels But UVic Has Not? The High Cost of Industry Influence," Policy Note, June 16, 2020, https://www.policynote.ca/divest-industry-influence/.

54. Suzanne Fortier, E-Mail to the McGill Community on behalf of the Board of Governors, December 5, 2019.

55. CAMSR, "Report to the Board of Governors," McGill University, Montreal, QC, https://www.mcgill.ca/boardofgovernors/files/boardofgovernors/13._gd19-29_camsr_report.pdf; Barney and Nystrom, "McGill Is Still Investing in Fossil Fuels."

56. MCSI, MCSI Carbon Footprint Index Ratio Methodology, Toronto, ON: MSCI, https://www.msci.com /documents/1296102/6174917/MSCI+Carbon+Footprint+Index+Ratio+Methodology.pdf/6b10f849-da51-4db6-8892e8d46721e991.

57. Allison Hanes, "McGill Prof Practices What He Teaches, Quits in Divestment Protest," Montreal Gazette, January 16, 2020, https://montrealgazette.com/opinion/columnists/hanes-mcgill-prof-practises-what-he-teaches-quits-in-dive stmentprotest.

58. Environmental and Climate Change Canada (ECCC), Canada's Mid-Century Long-Term Low-Greenhouse Gas Development Strategy, Ottawa, ON: Government of Canada, https://unfccc.int/files/focus/long-term_strategies lapplication/pdf/canadas_mid-century_long-term_strategy.pdf; Chris Chipello, "McGill Commits to Carbon Neutrality By 2040," McGill Newsroom, November 28, 2017, https://mcgill.ca/newsroom/channels/news/mcgill-commits-carbonneutrality-2040-283092. 
in some of the world's top oil, gas, and pipeline corporations. To invest in something is to bank on its expansion. At the federal level, our government is spending billions of tax dollars propping up failing pipeline ventures, and otherwise expanding some of the world's most polluting extraction projects. ${ }^{59}$ One monstrous example implicating both the university and the government is McGill's five-million-dollar investment in TC Energy (as of June 30th, 2020) - the pipeline company on whose behalf the Royal Canadian Mounted Police invaded Indigenous land in February 2020, touching off country-wide protests. ${ }^{60}$

For both McGill and Canada, the fundamental problem is corporate control. ${ }^{61}$ As noted above, the majority of McGill's governors represent a corporate elite rather than students, faculty, staff, alumni, or Québec or Canadian society. ${ }^{62}$ This ruling class does not care as much as the general public does about our deteriorating biosphere. ${ }^{63}$ Meanwhile, this same class of people are stifling Canadian environmental policy. ${ }^{64}$ It is time for the rest of us to de-throne this over-privileged minority, and exercise our democratic rights to policies that truly protect and promote life, on the only planet in the universe known to contain life.

\section{Epilogue}

The world has changed since I first submitted this article for consideration in March 2020. I thus thank the editor for a chance to add this epilogue on how subsequent developments relate to the points in the main text above. I focus on Oxford University's historic move from partial to full divestment, the pandemic's effect on McGill University's stocks in fossil fuel vs. other industries, and the implementation of the latter's "de-carbonization" plan.

Oxford's divestment shows what a difference workplace democracy can make. In April the university's "Congregation" passed the following resolution:

Congregation instructs Council ["the University's executive governing body"] to divest from the fossil fuel industry, including but not limited to the Carbon Underground's top 200 (https://fossilfreefunds.org /carbon-underground-200), requiring an immediate restriction on all direct investment in any fossil fuel exploration and extraction companies and an immediate restriction on new investments in funds which invest primarily in fossil fuel extraction companies (including coal, oil and gas, exploration and extraction, as an addition to Oxford University's existing restriction on thermal coal and tar sands). ${ }^{65}$

59. Christophe McGlade and Paul Ekins, "The Geographical Distribution of Fossil Fuels Unused When Limiting Global Warming to $2^{\circ} \mathrm{C}$," Nature 517 (2015): 187-190, https://doi.org/10.1038/nature14016; Elizabeth May, "Elizabeth May Asks, 'At What Cost, Canada?"” National Observer, February 12, 2020, https://www.nationalobserver.com/2020/02/12/ opinion/elizabeth-may-asks-what-cost-canada.

60. Emma McIntosh, "RCMP Breach Final Wet'suwet'en Camp in the Path of Costal GasLink Pipeline," National

Observer, February 10, 2020, https://www.nationalobserver.com/2020/02/10/news/rcmp-breach-final-wetsuweten-camppath-coastal-gaslink-pipeline; Helen Wu, "Divest McGill Obstructs Entrances to James Administration for Divestment,"

McGill Tribune, February 18, 2020, http://www.mcgilltribune.com/news/divest-mcgill-obstructs-entrances-to-the-jamesadministration-building-for-divestment-18022020/.

61. See: https://www.corporatemapping.cal.

62. CAUT, "Do You Know Who Sits on Your Board?"

63. Gregory Mikkelson, "Environmental Values, Human Nature, and Economic Democracy," Human Ecology 45 (2017): 131-134, https://doi.org/10.1007/s10745-016-9877-y.

64. Donald Gutstein, The Big Stall: How Big Oil and Think Tanks are Blocking Action on Climate Change in Canada (Toronto: Lorimer, 2018).

65. Congregation, "Fossil Fuel Divestment and Net Zero Investment Resolution," University of Oxford Gazette, March 26, 2020, 357, https://gazette.web.ox.ac.uk/files/26march2020-no5272pdf; see also: https://governance.admin.ox.ac.uk/counci 1/about-council. 
Congregation "consists of about 5,500 members, comprising academic staff, heads and other members of governing bodies of colleges and societies and senior research, computing, library and administrative staff." ${ }^{66}$ Crucially, at Oxford "Congregation is the sovereign body of the University." ${ }^{67}$ Unfortunately, this body lacks any student representation. But it is a leading example of workplace democracy - especially as compared to McGill's sovereign Board, consisting primarily of a self-selected group of wealthy individuals who neither work nor study at the university.

If McGill had a more democratic structure - or at least an administration and Board responding in a more enlightened way to the manifest will of its people - the university would have divested years ago. Moreover, evidence suggests McGill would have come out tens of millions of dollars ahead. ${ }^{68}$ To bring that evidence up to date, I tracked the prices of 30 stocks the university held in its endowment portfolio as of December 31st, 2018. That date came a few months after the Senate divestment resolution, nearly four years after DM's second expression of concern asking the Board to divest, and nearly six years after their first - in other words, after McGill had had ample time to divest. Among the university's 647 direct investments at the end of 2018, I tracked the 10 in fossil fuel with a value of at least $\$ 500,000$, and for each of those 10, the next-biggest and the next-smallest investment. For example, since McGill held \$5.4 million worth of Suncor stock at the end of 2018, I also tracked the next-largest investment the Royal Bank of Canada (\$9.2 million) and the next-smallest investment Brookfield Asset Management (\$5.2 million). Between December 31st, 2018 and September 11th, 2020, the 20 stocks outside the fossil fuel industry gained a weighted average of $16 \%$ (weighted, that is, according to the amount invested at the end of 2018; please contact the author for this and other details of the calculations). In contrast, the fossil fuel stocks lost a weighted average of $27 \%$. This is a huge gap of $43 \%$, indicating that the Board's refusal to divest has again cost the university tens of millions.

Finally, a few more words about the plan to "de-carbonize" the McGill endowment, that the Board approved in December 2019 instead of divestment. Through this plan, the administration and Board persist in letting fossil fuel corporations off the hook for any damage caused by their product after they sell it. The plan's definition of a given company's "carbon footprint" includes only the greenhouse gas emissions involved in making their product or delivering their service. ${ }^{69}$ This is morally repugnant, just as it would have been to let tobacco companies off the hook for any damage caused by their product after they sell it. (In addition to divesting from South Africa in the 1980's, McGill also divested from tobacco in the early 2000s). It is also politically ineffectual, since it diffuses responsibility too widely to prod the government into the necessary turn away from fossil fuel production. That said, many fossil fuel corporations do also have relatively carbon intensive production processes. This creates pressure to drop at least some of these corporations from the portfolio. However, the "de-carbonization" plan's definition of "carbon footprint" may count pipeline companies as relatively carbon-efficient, since they're not actually burning most of the stuff they pipe. This leaves the door open for McGill to keep some of its most harmful fossil fuel investments.

The June 30th, 2020, update of McGill's endowment holdings shows how the Board has implemented its "de-carbonization" plan so far. First, the good news: the university has dropped all eight of the investments in top-100 coal companies that it held as of March 31st, 2020, as well as its investments

66. “Congregation," Governance and Planning, University of Oxford, last modified November 15, 2020, http://governance .admin.ox.ac.uk/congregation.

67. "Congregation."

68. Heaps, "What Kind of World."

69. MCSI, MCSI Carbon Footprint. 


\section{$12 \diamond$ Mikkelson}

in the top-100 oil and gas companies BP and Shell. However, the bad news is that McGill not only held onto, but increased, the already-large amounts invested in the pipeline companies TC Energy (\$5.1 million as of June 30th), Pembina (\$2.4 million), and Enbridge (\$1.2 million). These are the companies creating, expanding, and/or operating such notorious pipelines as the Coastal GasLink (as noted above); Keystone XL; and Lines 3 and 9. Moreover, the university also increased its major investments in the world's two largest tar sands companies - Canadian Natural Resources (CNR; \$1.8 million) and Suncor (\$3.4 million).

It is puzzling how the university can do this and still follow its "de-carbonization" plan, since digging tar out of sand emits a huge amount of greenhouse gas. ${ }^{70}$ It may be that the Board sold off a huge number of other stocks with higher-than-average "carbon footprints" in order to hold onto CNR and Suncor. The number of direct investments in McGill's portfolio remained stable at around 650 between early 2018, when I first started tracking it, and early 2020. But that number plummeted to 431 stocks as of mid-2020. Did the Board keep CNR and Suncor in the mix as a matter of class solidarity with their owners, or perhaps in the hopes of future donations to the university from these corporations? ${ }^{71}$ Whatever the reasons for such decisions, they come at tremendous ecological, moral, reputational, and now even financial cost. The latter are most readily quantified: CNR stock lost $26 \%$ of its value between December 31st, 2018 and September 11th, 2020; while Suncor stock lost $51 \%$ of its value over the same period. ${ }^{72}$

70. McGlade and Ekins, "The Geographical Distribution."

71. For an acknowledgement of Suncor's past donations, see: "Corporate and Foundation Donors," Faculty of Engineering, McGill University, last modified November 15, 2020, https://www.mcgill.ca/engineering/alumni/oursupporters/corporate-and-foundation-donors.

72. See: https://www.bloomberg.com. 


\section{Bibliography}

Ansar, Atif, Ben Caldecott, and James Tilbury. Stranded Assets and the Fossil Fuel Divestment Campaign: What Does Divestment Mean for the Valuation of Fossil Fuel Assets? Oxford, UK: Smith School of Enterprise and the Environment, 2013. http://www.smithschool.ox.ac. uk/publications/reports/SAP-divestment-report-final.pdf.

Asheim, G. B., T. Fæhn, K. Nyborg, M. Greaker, C. Harstad, D. Lund, K. E. Rosendahl. "The Case For A Supply-Side Climate Treaty.” Science 365 (2019): 325-327. https://science.sciencemag.org/ content/365/6451/325.full.

Bachher, J. S. and R. Sherman. "UC Investments Are Going Fossil Free. But Not Exactly For the Reasons You May Think.” Los Angeles Times, September 16, 2019. https://www.latimes.com/ opinion/story/2019-09-16/divestment-fossil-fuel-university-of-california-climate-change.

Barney, Darrin. and Derek Nystrom. "McGill Is Still Investing in Fossil Fuels And Has No Plans To Stop.” National Observer, December 9, 2019. https://www.nationalobserver.com/2019/ 12/09/opinion/mcgill-still-investing-fossil-fuels-and-has-no-plans-stop.

Barney, Darin and Derek Nystrom. "McGill Profs Resign from Board of Governors Over Investment in Fossil Fuels.” National Observer, April 22, 2019. https://www.nationalobserver.com/2019/04 /22/opinion/mcgill-profs-resign-board-governors-over-investment-fossil-fuels.

Broome, John. Climate Matters: Ethics in a Warming World. New York: W. W. Norton, 2012.

Brown, Peter G., Darin Barney, Maggie Kilgour, Steven Jordan, Peter Caines, Gregory M. Mikkelson, Henry Mintzberg, et al., "Letter from 12 Angry Professors." 2016. https://d770c282-fece-44939934-28fdee2db642.filesusr.com/ugd/bb851e_ad664684cb2a45e c86f25d1d48f218e6.pdf.

CAMSR (Annotated by MFL4D). "Report to the Board on Divest McGill Submission of February 2015." Montreal, QC: McGill University, 2016. https://d770c282-fece-4493-9934-28fdee 2db642 .filesusr.com/ugd/bb851e_d972 486e9a194c15aaee5d74c0dc540a.pdf.

CAMSR. "Report to the Board of Governors." Montreal, QC: McGill University, 2019. https://www. mcgill.ca/boardofgovernors/files/boardofgovernors/13. gd19-29 camsr report.pdf.

CAUT. “Do You Know Who Sits On Your Board?” CAUT Bulletin 63, no. 7 (2016): 14-19. https://www.caut.ca/bulletin/2016/09/do-you-know-who-sits-your-board.

Chipello, Chris. "McGill commits to carbon neutrality by 2040." McGill Newsroom, November 28, 2017. https://mcgill.ca/newsroom/channels/news/mcgill-commits-carbon-neutrality-2040-283092.

Congregation. "Fossil Fuel Divestment and Net Zero Investment Resolution." University of Oxford Gazette, March 26, 2020. https://gazette.web.ox.ac.uk/files/26march2020-no5272 pdf. 
Duff, James and Robert O. Berdahl. University Government in Canada: Report of a Commission Sponsored by the Canadian Association of University Teachers and the Association of Universities and Colleges in Canada. Toronto: University of Toronto Press, 1966.

Environment and Climate Change Canada (ECCC). Canada's Mid-Century Long-Term Low-Greenhouse Gas Development Strategy. Ottawa, ON: Government of Canada, 2016. https://unfccc.int/files/focu s/long-term_strategies/application/pdf/canadas_mid-century_long-term_strategy.pdf.

Fahmy, Gabrielle. "Divest McGill Movement Gets Backing from Arts Faculty.” CBC News, December 3rd, 2015. https://www.cbc.ca/news/canada/montreal/divest-mcgill-faculty-arts-vote-1.3348997.

Gordon, M. "McGill recognizes total divestment." McGill Daily, November 20th, 1985.

Gray-Donald, David. "McGill Budges Slightly Under Pressure From Fossil Fuel Divestment Campaign." Rabble, April 4, 2016. https://rabble.ca/news/2016/04/mcgill-budges-slightly-under-pressurefossil-fuel-divestment-campaign.

Grooten, M. and R. E. A. Almond, eds. Living Planet Report 2018: Aiming Higher. Gland, CH: Worldwide Fund for Nature, 2018. https://www.worldwildlife.org/pages/living-planet-report-2018.

Gutstein, Donald. The Big Stall: How Big Oil and Think Tanks Are Blocking Action on Climate Change in Canada. Toronto: Lorimer, 2018.

Hanes, Allison. "McGill Prof Practises What He Teaches, Quits in Divestment Protest." Montréal Gazette, January 16th, 2020. https://montrealgazette.com/opinion/columnists/hanes-mcgill-prof-practiseswhat-he-teaches-quits-in-divestment-protest.

Heaps, Toby A. A. "What Kind of World Do You Want To Invest In? Corporate Knights, November 16, 2015. https://www.corporateknights.com/channels/responsible-investing/ fossil-fuel-investmentscost-major-funds-billions-14476536.

JGSC. "Report.” Montreal, QC: McGill University, 1967.

Kirsch, Alison, Jason Opeña Disterhoft, Grant Marr, Paddy McCully, Ayse Gürsöz, Greig Aitken, Clare Hamlett, et al. Banking on Climate Change: Fossil Fuel Finance Report Card 2020. San Francisco, CA: Rainforest Action Network, 2020. https://www.ran.org/publications/ banking-on-climatechange-fossil-fuel-finance-report-2020.

Landrigan, Philip J., Richard Fuller, Nereus J. R. Acosta, Olusoji Adeyi, Robert Arnold, Niladri Basu, Abdoulaye Bibi Baldé, et al. "The Lancet Commission on Pollution and Health.” Lancet 391, no. 10119 (2018): 462-512. https://doi.org/10.1016/S0140-6736(17)32345-0.

Lukacs, Martin. "Why Graduates of a Top Canadian University Are Returning Their Diplomas.” Guardian, March 15, 2016. https:www.theguardian.com/environment/true-north/2016/mar/15/why-graduates 
-of-a-top-canadian-university-are-returning-our-diplomas.

May, Elizabeth. "Elizabeth May asks, “At What Cost, Canada?"” National Observer, February 12, 2020. https://www.nationalobserver.com/2020/02/12/opinion/elizabeth-may-asks-what-cost-canada.

McGlade, Christophe, and Paul Ekins. "The Geographical Distribution of Fossil Fuels Unused When Limiting Global Warming to $2^{\circ}$ C." Nature 517 (2015): 187-190. https://www.nature.com/articles/ nature14016.

McIntosh, Emma. "RCMP Breach Final Wet'suwet'en Camp in The Path of Coastal GasLink Pipeline." National Observer, February 10, 2020. https://www.nationalobserver.com/2020/02/10/news/ rcmp-breach-final-wetsuweten-camp-path-coastal-gaslink-pipeline.

Meinshausen, Malte, Nicolai Meinshausen, William Hare, Sarah C. B. Raper, Katja Frieler, Reto Knutti, David J. Frame, et al. "Greenhouse-Gas Emission Targets for Limiting Global Warming to $2{ }^{\circ} \mathrm{C}$." Nature 458 (2009): 1158-1162. https://www.nature.com/articles/nature 08017.

Mikkelson, Gregory M. "Environmental Values, Human Nature, and Economic Democracy.” Human Ecology 45 (2017): 131-134. https://link.springer.com/article/10.1007/s10745-016-9877-y.

MSCI. MSCI Carbon Footprint Index Ratios Methodology. Toronto: MSCI, 2017. https://www.msci.com/ documents/1296102/6174917/MSCI+Carbon+Footprint+Index+Ratio+Methodology.pdf/6b10f84 9-da51-4db6-8892-e8d46721e991.

Oreskes, Naomi, and Erik M. Conway. Merchants of Doubt: How a Handful of Scientists Obscured the Truth on Issues from Tobacco Smoke to Climate Change. New York: Bloomsbury, 2011.

Otto, Ilona M., Jonathan F. Donges, Roger Cremades, Avit Bhowmik, Richard J. Hewitt, Wolfgang Lucht, Johan_Rockström, et al. "Social Tipping Dynamics for Stabilizing Earth's Climate By 2050." Proceedings of the National Academy of Sciences 117 (2020): 2354-2365. https://www.pnas.org/ content/117/5/2354.

Patriquin, Martin. "McGill Should Stop Investing in Fossil Fuels. Montreal Gazette, September 5, 2018. https://montrealgazette.com/opinion/columnists/martin-patriquin-mcgill-should-stop-investing-infossil-fuels.

Ripple, William J., Christopher Wolf, Thomas M. Newsome, Phoebe Barnard, and William R. Moomaw. "World Scientists' Warning of A Climate Emergency." BioScience 70, no. 1 (2020): 8-12. https://academic.oup.com/bioscience/article/70/1/8/5610806.

Rowe, James, Elora Adamson, Jason Hemmerling, and William Caroll. "Why Has UBC Divested from Fossil Fuels but UVic Has Not? The High Cost of Industry Influence.” Policy Note, June 16, 2020. https://www.policynote.ca/divest-industry-influence. 
Saxifrage, B. "Canadians Are Making a Supersized Gamble on Climate and The Economy." National Observer, February 21, 2017. https://www.nationalobserver.com/2017/02/21/ opinion/canadiansare-making-supersized-gamble-climate-and-economy.

Secretariat. Statutes of McGill University. Montreal, QC: McGill University, 2017. https://www.mcgill.ca /secretariat/files/secretariat/statutes_of_mcgill_university.pdf.

Senate. "Report of the Steering Committee." September 12, 2018. Montreal, QC: McGill University. https://mcgill.ca/senate/files/senate/2._report_of_the_steering_committee_0.pdf.

Smith, Joshua Emerson. "UC Academic Senate Calls on Regents to Divest from Fossil Fuels." San Diego Union Tribune, July 17, 2019. https://www.sandiegouniontribune.com/news/environment/story /2019-07-17/uc-professors-call-on-regents-to-divest-from-fossil-fuels.

Staff. "Experts Weigh in on Climate Change, Divestment.” McGill Reporter, April 6, 2016. https://reporter.mcgill.ca/experts-weigh-in-on-climate-change-divestment.

Taylor, Matthew. "Half of UK Universities Have Committed to Divest from Fossil Fuel." Guardian, January 13, 2020. https://www.theguardian.com/environment/2020/jan/13/half-of-uk-universitie s-have-committed-to-divest-from-fossil-fuel.

Thomas, Chris D., Alison Cameron, Rhys E. Green, Michel Bakkenes, Linda J. Beaumont, Yvonne C. Collingham, Barend F. N. Erasmus, et al. "Extinction Risk from Climate Change." Nature 427 (2004): 145-148. https://www.nature.com/articles/nature02121.

Trinks, Arjan, Bert Scholtens, Machiel Mulder, and Lammertjan Dam. "Fossil Fuel Divestment and Portfolio Performance.” Ecological Economics 146 (2018): 740-748. https://doi.org/10. $\underline{1016 / j . e c o l e c o n .2017 .11 .036 .}$

Ward, Bob. "Letter to Nick Thomas of Exxon.” London: Royal Society of London, 2006. https://royalsociety.org/ /media/Royal_Society_Content/policy/publications/2006/8257.pdf.

Wu, Helen. "Divest McGill Obstructs Entrances to James Administration for Divestment." McGill Tribune, February 18, 2020. http://www.mcgilltribune.com/news/divest-mcgill-obstructs-entrances-to-thejames-administration-building-for-divestment-18022020/. 